\title{
Model Integrasi Faktor Insaniah dalam Pelaksanaan ISO 9000: Analisis dari Perspektif Islam
}

\author{
Siti Arni Basir \\ Universiti Malaya, sitiarni@um.edu.my \\ Hasan Al-Banna Mohamed \\ Universiti Pertahanan Malaysia, hasanalbanna@upnm.edu.my \\ Sharifah Hayaati Syed Ismail \\ Universiti Malaya, sashsiaq@um.edu.my \\ Ilhaamie Abdul Ghani Azmi \\ Universiti Malaya, amieazmi@um.edu.my
}

\begin{abstract}
Abstrak
Kajian mengenai ISO 9000 menjadi topik popular dalam kalangan sarjana pengurusan kualiti. Walau bagaimanapun, kajian-kajian lepas lebih menjurus kepada langkah-langkah pelaksanaan, aspek teknikal, motif, cabaran dan faedah. Manakala aspek mengenai budaya dan kemanusiaan masih amat kurang dikaji. Faktor kemanusiaan atau insaniah semakin mendapat perhatian dalam kalangan sarjana kerana keupayaannya untuk membawa kesan signifikan kepada keberkesananan dalam melaksanakan pelbagai program pengurusan. Oleh itu, kajian ini bertujuan membangunkan model yang menggambarkan integrasi faktor insaniah dalam perlaksanaan ISO 9000 yang dibincangkan dari perspektif Islam. Hasil kajian telah mengenal pasti enam faktor insaniah dalam pelaksanaan ISO 9000 iaitu kepimpinan, latihan dan pendidikan, kerjasama, fokus kepada pelanggan, ganjaran dan komunikasi. Faktor insaniah yang diketengahkan memerlukan penyelarasan-penyelarasan tertentu agar ia selari dengan kehendak Islam. Integrasi faktor insaniah akhirnya berupaya membawa impak positif iaitu pelaksanaan ISO 9000 yang berkesan. Model ini boleh digunakan oleh para pengurus sebagai panduan untuk meningkatkan keberkesanan perlaksanaan ISO 9000 di organisasi masing-masing.
\end{abstract}

Kata kunci: pelaksanaan ISO 9000, faktor insaniah, integrasi, perspektif Islam

Integration of Insaniyyah Factor Model in ISO 9000 Implementation: An Analysis from Islamic Perspective

\begin{abstract}
The study of ISO 9000 has become a popular topic among scholars of quality management. However, previous studies focus more on implementation measures, technical aspects, motives, challenges and
\end{abstract}


benefits of ISO 9000 implementation. On the other hand, aspects of culture and humanity were less studied. Human or insaniyyah factors have gained attention among scholars because of its ability to convey significant impact to the effectiveness of implementation of various management programs. Therefore, this study aims to develop a model that demonstrates the integration of soft or insaniyyah factors into the ISO 9000 implementation program. The insaniyyah factors are discussed from Islamic perspective. The study has identified six insaniyyah factors that can be integrated into ISO 9000 implementation that is leadership, training and education, cooperation, customer focus, reward and communication. Insaniyyah factors which are highlighted require certain adjustments to ensure that they are consistent with the requirements of Islam. Integration of insaniyyah factors ultimately is able to bring positive impact on the effective implementation of ISO 9000. This model can be used by managers as a guide to enhancing the effectiveness of the implementation of ISO 9000 in their respective organisations.

Keywords: ISO 9000 implementation, insaniyyah factors, integration, Islamic perspective

\section{Pendahuluan}

Para pengguna dan pelanggan hari ini mahukan organisasi sama ada organisasi di sektor awam mahu pun swasta menawarkan produk dan perkhidmatan yang bermutu tinggi. Desakan ini telah membawa kepada penggubalan dan kewujudan sistem pengurusan kualiti (SPK) dalam sesebuah organisasi. ${ }^{1}$ Pelbagai kaedah, sistem atau program kualiti telah dicipta untuk membantu organisasi untuk mencapai kecemerlangan dalam penyediaan perkhidmatan ataupun produk. Antara program kualiti yang diamalkan di seluruh dunia pada masa kini seperti Pengurusan Kualiti Menyeluruh (TQM), Anugerah Kualiti Balgridge, Model Kualiti Eropah, Kaizen, Amalan 5S atau EKSA (Ekosistem Kondusif Sektor Awam) dan Sistem Pengurusan Kualiti (SPK) ISO 9000. ISO 9000 merupakan antara sistem pengurusan kualiti yang paling popular iaitu sehingga 2013, sebanyak 1,129,446 sijil ISO 9000 telah dikeluarkan di seluruh dunia ${ }^{2}$. Piawaian ISO 9000 sebagai sistem

1 Barry G. Dale, Managing Quality, ed. ke-3 (London: Blackwell Publishers, 1999).

2 ISO Standard, Executive Summary, The ISO Survey of Management System Standard Certifications-2013, dicapai 3 January 2015, http://www.iso.org/iso /iso_survey_executive-summary.pdf?v2013, Geneva 2015. 
kualiti yang diasaskan sejak tahun 1987 yang sentiasa diperbaiki dari segi kandungannya agar dapat memenuhi pelbagai jenis perniagaan dan perkhidmatan. ISO 9000 yang terdapat pada hari ini lebih bersifat asas dan umum, maka tidak hairanlah dengan pemahaman yang tepat terhadap sistem tersebut membolehkan banyak organisasi dapat melaksanakan ISO 9000 dengan jayanya. ISO 9000 pada hari ini bukan hanya diamalkan di sektor swasta dan perkilangan, tetapi juga telah dilaksanakan secara meluas di sektor awam dan perkhidmatan.

Walaupun banyak kajian tentang ISO 9000 telah dilakukan, namun ia lebih menjurus kepada aspek perlaksanaan, konsep, motif, cabaran dan faedah. Kajian mengenai aspek-aspek lain seperti budaya dan kemanusiaan masih amat kurang diberi perhatian. Oleh itu, kajian ini bertujuan membangunkan model yang menggambarkan integrasi faktor insaniah dalam pelaksanaan ISO 9000. Integrasi faktor insaniah ini turut dibincangkan daripada perspektif Islam. Secara ilmiahnya, kajian ini akan mengisi kelompangan berkenaan dengan isu yang berkait dengan aspek kemanusiaan dalam sorotan literatur berkenaan dengan ISO 9000. Model yang dibangunkan dalam kajian ini akan menonjolkan kepentingan faktor insaniah dalam usaha merealisasikan pelaksanaan ISO 9000 yang berkesan. Secara praktikalnya, model ini akan menjadi panduan kepada pihak pengurusan untuk mereka menyuntik faktor-faktor insaniah dalam pelaksanaan ISO 9000 di organisasi masing-masing.

\section{Latar Belakang dan Perkembangan ISO 9000}

Menurut Bendell $(2000)^{3}$, asal-usul siri standard ISO 9000 sebenarnya berasal dari standard perolehan ketenteraan pada Perang Dunia Kedua. Pada 1979, United Kingdom yang merupakan ahli kepada Organisasi Standard Antarabangsa (International Organisation of Standardization - ISO) dan juga Suruhanjaya Antarabangsa Teknikal Elektro telah menghantar kertas cadangan kepada ISO agar jawatankuasa teknikal ditubuhkan untuk membangunkan standard antarabangsa bagi jaminan kualiti. Akhirnya, jawatankuasa teknikal yang dikenali sebagai ISO/TC176 telah ditubuhkan dengan matlamatnya untuk

3 Tony Bendell, The Implications of the Changes to ISO 9000 for Organisational Excellence, Measuring Business Excellence 4, no.3 (1996), 23-29. 
membangunkan piawaian (standard) antarabangsa jaminan kualiti, tekniknya dan juga panduan pelaksanaannya. Ahli-ahli jawatankuasa ini terdiri daripada mereka yang mempunyai pelbagai bidang kepakaran yang datang daripada sektor industri, institusi penyelidikan, agensi kerajaan, persatuan pengguna dan badan-badan antarabangsa dari seluruh dunia ${ }^{4}$.

Matlamat jawatankuasa ISO/TC176 tersebut adalah untuk menggubal standard sistem pengurusan kualiti yang bersifat umum yang boleh diaplikasikan secara menyeluruh di peringkat antarabangsa. Standard tersebut juga tidak harus ditujukan kepada sektor industri semata-mata. Tugasan jawatankuasa ISO/TC176 banyak dipengaruhi dan dipermudahkan dengan standard kualiti antarabangsa sedia ada pada masa itu terutamanya standard kualiti yang daripada Britain dan Kanada. Pada masa tersebut, BS 5750 telah digunapakai di Britain. Jawatankuasa ISO/TC176 telah menaiktarafkan BS 5750 menjadi standard ISO 9000.

Pada 1987, standard ISO 9000 telah diterbitkan. Standard tersebut menyediakan prinsip dan garis panduan untuk menilai kualiti dalam proses perniagaan dan perkhidmatan ${ }^{5}$. Standard tersebut telah dinilai semula dan diubah sedikit pada $1994^{6}$. Standard ISO perlu dinilai semula setiap lima tahun sekali. Penilaian semula pada 1994 bukanlah bertujuan untuk menambah keperluan atau klausa baru kepada standard ISO 9000, tetapi untuk memperjelaskan lagi standard tersebut bagi memudahkan lagi proses penilaian dan pelaksanaannya ${ }^{7}$.

Magd dan Curry menghuraikan piawaian ISO 9000: 1994 seperti berikut: ${ }^{8}$

Standard Fokus

ISO 9000 Standard pengurusan dan jaminan kualiti untuk pemilihan dan penggunaan.

ISO 9001 Model sistem kualiti untuk jaminan kualiti untuk organisasi yang prosesnya termasuk mereka bentuk,

4 Barry G. Dale, Managing Quality, n.p.

5 Christian N. Madu, Handbook of TQM (London: Kluwer Academia, 1998).

6 Tony Bendell, The Implications of the Changes to ISO 9000 for Organisational Excellence, Measuring Business Excellence 4, no.3 (2000), 11-14.

7 Barry G. Dale, Managing Quality, n.p.

8 Hesham Magd and Adrienne Curry, ISO 9000 and TQM, The TQM Magazine 15 , no.3 (2003), 244-256. 
pembangunan, pembuatan, pemasangan dan perkhidmatan.

ISO 9002 Model sistem kualiti untuk jaminan kualiti untuk organisasi yang prosesnya termasuk pembuatan dan pemasangan, tetapi tidak terlibat dalam mereka bentuk dan pembangunan.

ISO 9003 Model sistem kualiti untuk jaminan kualiti untuk organisasi yang prosesnya termasuk penilaian dan pemeriksaan bagi memenuhi keperluan kualiti produk dan perkhidmatan.

ISO 9004 Garis panduan pengurusan kualiti dan elemen sistem kualiti.

Terdapat pertumbuhan yang jelas dalam pensijilan ISO 9000 pada dekad 1990an. Jumlah pensijilan di seluruh dunia telah meningkat dari 27,000 pada 1993 kepada 274,040 pada 1999. Walaupun standard ISO 9000 awalnya dilaksanakan di perkilangan dan pembuatan, kesungguhan daripada kebanyakan kerajaan di dunia dalam melaksanakannya telah menjadikan pentadbiran awam juga semakin terlibat dalam pelaksanaan ISO 9001.

Standard ISO 9000 versi 1987 dan versi 1994 hanya menghendaki organisasi untuk menyediakan sistem kualiti yang didokumentasikan dan memastikan bahawa ianya hanya mengeluarkan barangan dan perkhidmatan seperti yang telah dinyatakan dalam dokumen kualiti tersebut. Walau bagaimanapun, jika organisasi berjaya memenuhi tuntutan dokumen kualiti, ini tidak bermakna bahawa ia dapat menghalang organisasi daripada mengeluarkan barangan dan perkhidmatan yang berkualiti rendah. ISO 9000 versi 1987 dan versi 1994 tidak memberi penekanan kepada penambahbaikan berterusan dan langkah-langkah pencegahan.

Sehubungan dengan itu, Jawatankuasa Teknikal 176 pada 1998 telah mengkaji masalah berhubung dengan ISO 9000 dalam kalangan organisasi yang telah mendapat pensijilan ISO 9000. Kajian itu mendapati terdapat tujuh isu utama yang membawa kepada perlunya standard ISO 9000 diperbaharui. Manakala tujuh isu tersebut adalah ${ }^{9}$ :

9 Hesham Magd and Adrienne Curry, ISO 9000 and TQM, The TQM Magazine 15, no.3 (2003), 244-256. 
i. Mudah difahami, jelas, bahasa, terminologi, kurang penggunaan kertas.

ii. Integrasi kepada satu sistem sahaja.

iii. Penambahbaikan berterusan.

iv. Model proses, orientasi proses.

v. Penyesuaian kepada lain-lain standard pengurusan.

vi. Kepuasan pelanggan.

vii. Orientasi perniagaan.

Berdasarkan tujuh isu utama yang telah dibangkitkan tersebut, pada tahun 2000 standard ISO 9001 telah dinaiktaraf lagi dengan beberapa perubahan terhadap standard ISO 9000 versi 1994 telah dibuat. Gugusan standard ISO versi 1994 (ISO 9001, 9002, 9003 dan 9004) telah digabungkan menjadi satu standard ISO 9001: $2000^{10}$.

Piawaian atau Standard ISO 9000 versi 2000 adalah mengandungi siri-siri berikut ${ }^{11}$ :

Standard Fokus

ISO 9000 Perbendaharaan dan asas kepada sistem pengurusan kualiti - definisi terminologi dan standard

ISO $9001 \quad$ Keperluan sistem pengurusan kualiti - digunakan untuk menilai kepatuhan kepada keperluan sistem pengurusan kualiti (gabungan ISO 9001/9002/9003 dalam standard ISO 9000 versi 1994)

ISO 9004 Panduan sistem pengurusan kualiti untuk penambahbaikan berterusan - panduan untuk penambahbaikan sistem pengurusan secara berterusan.

9000:2000 adalah siri kepada tiga standard antarabangsa untuk Sistem Pengurusan Kualiti (SPK). Standard-standard tersebut menjelaskan cadangan-cadangan dan keperluan-keperluan untuk membangunkan dan menilai sistem pengurusan. ISO 9000 bukanlah standard untuk produk atau perkhidmatan. Standard ISO 9000 tidak menyediakan keperluan atau garis panduan untuk barangan atau produk mematuhinya. Tiada standard penerimaan dalam ISO 9000, justeru produk atau perkhidmatan tidak boleh

${ }^{10}$ John Beckford, Quality, ed. ke-16 (London: Routledge, 2002).

${ }^{11}$ Hesham Magd and Adrienne Curry, ISO 9000 and TQM, The TQM Magazine 15, no.4 (2003), 244-256. 
diukur dengan menggunakan standard ISO $9000^{12}$. ISO 9000 hanya menilai sistem pengurusan yang digunakan untuk mengeluarkan sesuatu produk atau perkhidmatan.

Hoyle (2001) menghuraikan tiga tujuan utama piawaian (standard) ISO 9000 iaitu $^{13}$ :

i. Tujuan ISO 9000 adalah untuk memberikan pengiktirafan kepada prinsip-prinsip asas sistem pengurusan kualiti dan penerangan terhadap terminologi yang digunakan dalam standard ISO 9000.

ii. Tujuan ISO 9001 adalah untuk menyediakan keperluankeperluan atau syarat-syarat, yang jika ianya dipatuhi, akan membolehkan organisasi membuktikan bahawa mereka mampu secara konsisten mematuhi keperluan-keperluan standard dalam usaha mereka mengeluarkan produk yang dapat memenuhi keperluan pelanggan. ISO 9001 menyatakan bahawa standard ISO 9000 boleh digunakan untuk menilai keupayaan organisasi dalam memenuhi kehendak pelanggan, keperluan undang-undang dan peraturan, dan keperluan organisasi itu sendiri.

iii. Tujuan ISO 9004 adalah untuk menyediakan garis panduan untuk memperbaiki keberkesanan dan kecekapan sistem pengurusan kualiti dan prestasi organisasi.

ISO 9001 dan 9004 dibangunkan sebagai standard yang melengkapi antara satu sama lain. Struktur mereka sama tetapi digunakan secara berasingan. Tujuan ISO 9004 bukanlah untuk menjadi garis panduan kepada ISO 9001. Walaupun ISO 9004 mengandungi keperluan-keperluan ISO 9001, ia tidak mengandungi penerangan berkaitan keperluan-keperluan tersebut atau pun panduan kaedah atau cara untuk mematuhinya ${ }^{14}$.

ISO 9000 telah diperbaiki lagi pada 2008 dan diberi nama ISO 9000: 2008 iaitu ISO 9000 versi tahun 2008. ISO 9000 versi 2008 dibangunkan bertujuan memberi penerangan lanjut kepada keperluan-keperluan yang terdapat dalam ISO 9000:2000. Ia juga bertujuan memperbaiki keserasian dan penyesuaian antara ISO 9000 dengan ISO 14000. ISO 9000:2008 tidak memperkenalkan

\footnotetext{
12 David Hoyle, ISO 9000 Quality Systems Handbook, $4^{\text {th }}$ ed., (Oxford: Butterworth Heinemann, 2001), n.p.

${ }^{13}$ David Hoyle, ISO 9000 Quality Systems Handbook, n.p.

${ }^{14}$ David Hoyle, ISO 9000 Quality Systems Handbook, n.p.
} 
apa-apa keperluan baru kepada keperluan ISO 9000 dan sama sekali tidak mengubah kandungannya ${ }^{15}$.

\section{Keperluan-keperluan ISO 9000}

Hoyle (2003) mendefinisikan keperluan-keperluan ISO 9001 sebagai syarat atau jangkaan yang telah dinyatakan yang mesti dipatuhi organisasi untuk mendapatkan pensijilan ISO $9001^{16}$. Sistem pengurusan kualiti (SPK) hendaklah dilaksanakan secara strategik, iaitu pertimbangan hendaklah diberikan kepada pelbagai isu seperti objektif organisasi, produk dan perkhidmatan yang akan ditawarkan, proses pengeluaran, serta saiz dan struktur organisasi ${ }^{17}$. SPK menggambarkan interaksi kesemua proses dalam organisasi menerusi aktiviti utama interaksi proses adalah untuk mengenal pasti keperluan pelanggan dan langkah-langkah bagi memuaskan hati pelanggan. ISO 9001 menggambarkan SPK sebagai integrasi lima keperluan utama iaitu:

i. Sistem pengurusan kualiti

ii. Tanggungjawab pengurusan

iii. Pengurusan sumber

iv. Realisasi produk

v. Pengukuran, analisis dan penambahbaikan berterusan.

Standard ISO 9000 mewawarkan pendekatan berasaskan proses iaitu mempercayai bahawa matlamat organisasi akan lebih mudah dicapai jika kesemua aktiviti dan sumber dalam organisasi diurus dengan menggunakan pendekatan $\operatorname{proses}^{18}$. Menurut keperluan ISO 9001, proses adalah “...rantaian aktiviti-aktiviti menggunapakai dan menguruskan sumber-sumber organisasi dalam usaha untuk mengubah input menjadi output". Seaver (2001) menekankan bahawa urusan organisasi atau perniagaan hendaklah dianggap sebagai proses dan bukan sebagai aktiviti-

15 ISO Standard, ISO 9000 - Quality management. Retrieved September 5, 2014, from http://www.iso.org/iso/home/standards/management-standards/iso_9000.htm, Geneva, 2014.

${ }^{16}$ Dayle Hoyle, ISO 9000:2000 (electronic resources): A-Z guide (Oxford: Butterworth Heinemann, 2003).

${ }^{17}$ ISO Standard, Quality Management System (QMS) Requirements (International Organization for Standardization, Geneva, 2005).

${ }^{18}$ Nadia Bhuiyan and Awan, H.M., ISO 9001:2000 Implementation, International Journal of Productivity and Performance Management 53, no.1 (2004), 10-17. 
aktiviti individu yang terpisah antara satu sama lain. Melihat perniagaan atau pentadbiran sebagai proses akan memudahkan pihak pengurusan untuk membuat keputusan yang tepat dalam memperbaiki pengurusan organisasi ${ }^{19}$.

\section{Langkah-Langkah Pelaksanaan ISO 9000}

Untuk melaksanakan ISO 9000 di sebarang organisasi, 13 langkah yang berikut perlu dipatuhi ${ }^{20}$. Pematuhan kepada langkah-langkah yang dicadangkan amatlah penting untuk memastikan kelancaran pelaksanaan program ISO 9000.

i. Mengenal pasti jurang

Proses perlaksanaan ISO 9001 bermula dengan analisis jurang antara sistem pengurusan sesebuah organisasi dengan keperluankeperluan yang terdapat dalam ISO 9001. Analisis jurang boleh dijalankan oleh organisasi itu sendiri ataupun penilai bebas.

ii. Memahami sistem kualiti

Pemahaman yang jelas terhadap ISO 9001 amat penting terutamanya bagi pengurus atasan. Selain daripada memahami ISO 9001 secara teori daripada buku panduan ISO 9001, para pengurus dan pekerja perlu dihantar untuk menjalani latihan berkaitan ISO 9001 secara formal.

iii. Polisi kualiti

Kualiti polisi perlu dirangka dengan fokus utamanya adalah kepuasan pelanggan. Polisi kualiti organisasi mestilah mencerminkan komitmen organisasi kepada usaha-usaha memperbaiki prestasi; sama ada prestasi produk atau perkhidmatan dan juga prestasi organisasi.

iv. Membentuk dan membangunkan kumpulan kerja

Jawatankuasa yang mengandungi pegawai daripada pelbagai jabatan hendaklah ditubuhkan. Jawatankuasa ini berperanan untuk membincangkan tentang pelaksanaan ISO 9001, menetapkan perancangan jangka masa, menentukan peruntukan sumber dan membincangkan hasil audit. Melalui jawatankuasa ini, bebanan

${ }^{19}$ Matt Seaver, Implementing ISO 9000:2000 (England: Gower Publishing Company, 2001).

${ }^{20}$ Nadia Bhuiyan and Nadeem Alam, A Case Study of Quality System Implementation in a Small Manufacturing Firm, International Journal of Productivity Management 54, no.3 (2005), 172-186. Lihat juga Bhatti M.I and Awan, H.M., Managerial Finance 29, no.7 (2003), 109-134. 
kerja boleh diagihkan dan pelbagai maklumat dapat dikongsi bersama. Penyertaan ahli jawatankuasa dari pelbagai jabatan akan membantu menyemarakkan semangat kerjasama dalam kalangan semua pekerja sesebuah organisasi.

v. Perwakilan pengurusan

Perwakilan pengurusan perlu ditubuhkan untuk mengemudi perubahan. Tanggungjawab utama perwakilan pengurusan adalah untuk memastikan pelaksanaan dan penyelenggaraan sistem kualiti menepati kehendak Standard ISO 9000.

vi. Menunjukkan komitmen

Pihak pengurusan hendaklah mengadakan dan mengagihkan sumber-sumber yang diperlukan untuk melancarkan pelaksanaan sistem kualiti. Para pengurus juga hendaklah mengambil bahagian secara aktif dalam program-program yang berkaitan dengan pelaksanaan ISO 9001 seperti mesyuarat, taklimat dan latihan.

vii. Pendokumentasian

Dokumentasi amat diperlukan agar perlaksanaan sistem kualiti menjadi lebih teratur. Dokumen-dokumen akan disusun dan dipecahkan menjadi manual kualiti dan manual prosedur kerja.

viii. Menentukan skop sistem kualiti

Sistem kualiti perlu dirangka dengan mengambil kira keadaan dan keperluan organisasi. Skop yang dipilih oleh sebuah organisasi mungkin tidak sesuai dengan organisasi yang lain.

ix. Mencuba pelaksanaan

Sistem kualiti yang dirangka mesti bersifat dinamik dan membantu dalam usaha-usaha mencapai objektif organisasi. Sistem kualiti tersebut juga mesti bersifat anjal iaitu boleh diubahsuai mengikut keperluan semasa yang sentiasa berubah. Tidak kurang penting juga, sistem tersebut juga mesti berkeupayaan membawa faedah kepada organisasi.

x. Mengadakan audit dalaman:

Audit dalaman secara konsisten hendaklah dijalankan terhadap sistem kualiti untuk mengesan sebarang kelemahan. Hasil audit dalam perlu dihantar kepada pihak pengurusan agar langkahlangkah penambahbaikan boleh diambil. Auditor-auditor dalaman yang terlatih ditugaskan untuk melaksanakan audit dalaman ini. Perkara utama yang selalu menjadi sasaran auditor adalah untuk menyemak sama ada prosedur kerja dipatuhi oleh pekerja ataupun tidak. 


\section{xi. Mengkaji prestasi}

Sistem kualiti yang dilaksanakan hendaklah sentiasa dikaji untuk memastikan ia membawa faedah yang diharapkan kepada organisasi. Kajian pengurusan terhadap pelaksanaan ISO 9001 amat penting untuk menilai sama ada objektif kualiti telah dicapai atau tidak.

xii. Audit

Pihak ketiga atau badan-badan akreditasi hendaklah dilantik untuk melaksanakan audit dalam usaha untuk mengesahkan bahawa sistem pengurusan kualiti yang dilaksanakan mematuhi keperluankeperluan ISO 9001. Sebagai persediaan untuk proses audit, para pengurus dan pekerja perlu memahami prinsip dan konsep asas ISO 9001. Rekod dan manual juga perlu disediakan untuk tujuan pengauditan organisasi akan menerima pensijilan ISO 9001 jika auditor berpuas hati bahawa sistem kualiti yang diguna pakai di organisasi tersebut menepati keperluan-keperluan atau syaratsyarat ISO 9001.

xiii. Mempertahankan pensijilan ISO 9001

Setelah mendapat pensijilan ISO 9001, organisasi hendaklah mempertahankan pensijilan tersebut. Matlamat mempertahankan pensijilan sistem pengurusan kualiti adalah untuk memperbaiki kualiti barangan atau perkhidmatan secara berterusan. Proses mempertahankan pensijilan ISO 9001 penuh dengan cabaran dan memerlukan kerjasama yang jitu daripada pelbagai pihak.

\section{Kedudukan Insan Menurut Islam}

Menurut Teori Ekonomi Klasik, para sarjana Barat meletakkan manusia sebagai salah satu faktor pengeluaran, di samping faktorfaktor lain iaitu tanah dan model. Tujuan majikan adalah untuk mengurus segala faktor pengeluaran bagi memenuhi matlamat utama kapitalis iaitu meminimumkan kos dan memaksimumkan pendapatan. Majikan juga menggunakan setiap individu pekerja selaku alat pengeluaran. Para pengkritik menyatakan, pengusaha bukannya mengurus, tetapi sebaliknya telah mengeksploitasi secara besar-besaran terhadap sumber-sumber pengeluaran termasuklah sumber manusianya. Falsafah ini telah mendominasi 
pemikiran golongan sarjana dan tuan-tuan perusahaan terutama semenjak meletusnya Revolusi Perindustrian pada abad ke $18 .^{21}$

Pandangan ini juga telah menyamatarafkan manusia, bahkan merendahkan kedudukannya berbanding dengan sumber atau bahan mentah yang tidak bernyawa. Hal ini bertentangan dengan pandangan Islam terhadap kedudukan manusia yang dianggap sebagai sebaik-baik kejadian. Firman Allah SWT yang bermaksud:

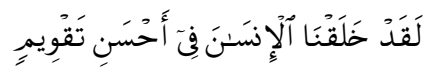

Al-Ṭin 95:4

Terjemahan: Sesungguhnya kami telah menciptakan manusia dalam bentuk yang sebaik-baiknya (dan berkelengkapan sesuai dengan keadaannya).

Islam sebenarnya amat mementingkan peranan manusia dalam segenap aspek kehidupan, termasuklah dalam pengurusan dan pentadbiran. Tanggungjawab manusia yang pertama adalah untuk menjadi hamba yang wajib mentaati perintah Allah SWT. Firman Allah SWT yang bermaksud:

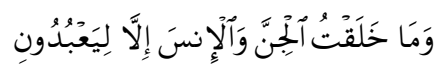

Al-Dhāriyāt 51:56

Terjemahan: Dan (ingatlah) Aku tidak menciptakan jin dan manusia melainkan untuk menyembah dan beribadat kepadaKu.

Walaupun menjadi hamba, tetapi Allah juga mengiktiraf dan memberi kebebasan kepada manusi a sebagai khalifah yang diberikan amanah untuk memakmurkan bumi ini. Firman Allah SWT yang bermaksud:

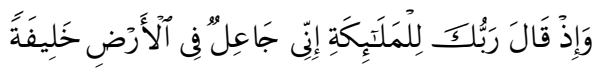

Al-Baqarah 2:30

Terjemahan: Dan (ingatlah) ketika Tuhan berfirman kepada malaikat kepada malaikat: Sesungguhnya Aku hendak menjadikan seorang khalifah di muka bumi.

${ }^{21}$ Huq, A., Human Dignity and Development: The Role of Material, Moral and Ethical Values, in Human development with Dignity, ed. Huq, A., (Kuala Lumpur: Cahaya Pantai, 1997), 9-45. 
Sebagai khalifah, manusia diberi kelebihan iaitu kelebihan dan kuasa untuk mentadbir makhluk-makhluk lain. Firman Allah SWT yang bermaksud:

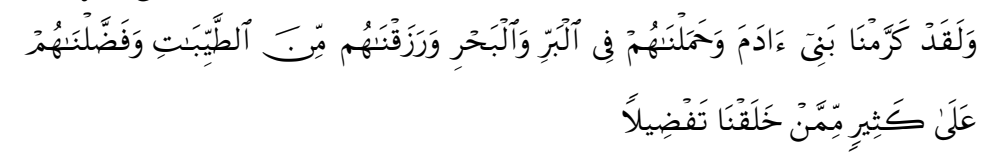

Al-Isrā' 17:70

Terjemahan: Dan sesungguhnya Kami telah memuliakan anak-anak Adam: dan Kami telah beri mereka menggunakan berbagai-bagai kenderaan di darat dan di laut; dan Kami telah memberikan rezeki kepada mereka dari benda-benda yang baik serta Kami telah lebihkan mereka dengan selebihlebihnya atas banyak makhluk yang telah Kami ciptakan.

Ayat-ayat al-Qur'an di atas menjelaskan bahawa manusia mempunyai kedudukan yang tinggi berbanding mahkluk-makhluk Allah yang lain.

Manusia bukan hanya mempunyai kedudukan yang tinggi berbanding makhluk-makhluk lain di segi hierarki, tetapi manusia juga mempunyai tanggungjawab yang perlu dilunaskan. Tanggungjawab tersebut boleh dikelompokkan sebagai tanggungjawab kepimpinan, tanggungjawab kepada masyarakat sekeliling, tanggungjawab kepada pekerja dan tanggungjawab untuk beramal baik secara berterusan. Ayat al-Qur'an dan hadis yang mempunyai kaitan dengan tanggungjawab tersebut adalah seperti berikut:

i. Tanggungjawab kepimpinan

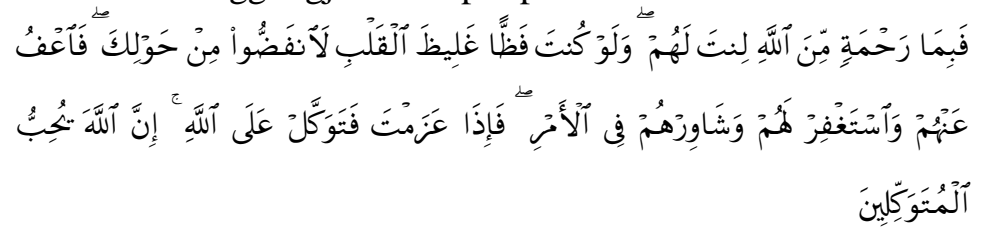

Āli-'Imrān 3:159

Terjemahan: Maka Dengan sebab rahmat dari Allah (kepadamu Wahai Muhammad), Engkau telah bersikap lemah-lembut kepada mereka dan kalaulah Engkau bersikap kasar lagi keras hati, tentulah mereka lari dari kelilingmu. Oleh itu maafkanlah mereka dan pohonkanlah ampun bagi 
mereka, dan juga bermesyuaratlah Dengan mereka Dalam urusan (peperangan dan hal-hal keduniaan) itu.

ii. Tanggungjawab kepada pengguna/ pelanggan

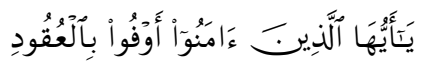

Al-Māidah 5:1

Terjemahan: Wahai orang-orang yang beriman, penuhi serta sempurnakanlah perjanjian-perjanjian.

iii. Tanggungjawab kepada pekerja (berkenaan upah)

Hadis Nabi yang bermaksud:

"Berikan sebahagian dari hasil usaha buruh kepadanya kerana tiada pekerja yang pulang tanpa ganjaran". ${ }^{22}$

iv. Tanggungjawab beramal baik dengan berterusan

$$
\text { أحب الأعمل إلى الله تعالى أدومها وإن قل. }
$$

Terjemahan: "Amalan yang disukai oleh Allah ialah yang berterusan walaupun sedikit". 23

\section{ISO 9000 dan Faktor Insaniah}

Kehoe (1996) menjelaskan bahawa pembangunan program dan budaya kualiti melibatkan sistem, teknik dan manusia; manusia merupakan faktor yang paling kritikal dan sukar untuk dibentuk dan dibangunkan. Beliau juga menekankan bahawa membangunkan sistem kualiti ISO 9000 dan teknik-teknik kualiti lebih mudah berbanding dengan kerja-kerja mengubah budaya dan motivasi manusia terhadap pembangunan program kualiti ${ }^{24}$. Pendapat Kehoe (1996) ini mempunyai kaitan dengan hujah Kotter (1996) yang menyatakan bahawa budaya organisasi sebenarnya sesuatu yang tidak dapat dilihat dan kerana itu, ia sukar untuk diubah $^{25}$. Sehubungan dengan ini, Cummings dan Worley (2001) menjelaskan terdapat tiga halangan kepada perubahan iaitu:

${ }^{22}$ Musnad Ahmad, dipetik oleh Afzal-Ur-Rahman, Doktrin Ekonomi Islam, terj. Zaharah Salleh (Kuala Lumpur: DBP, 1991), 299.

${ }^{23}$ Riwayat Muslim, Kitāb Solāh al-Musāfirin wa Qoșāruhā, Bāb Faḍāilah alA'mal wa al-Daim min Qiyāmī al-laylī wa Ghoiruha, no. hadith 1830 (Riyadh: Darussalam, 2000).

${ }^{24}$ D.F. Kehoe, The Fundamentals of Quality Management (London: Chapman Hall, 1996).

25 D.F. Kehoe, The Fundamentals of Quality Management, lihat juga John P. Kotter Leading Change: Why Transformation Effort Fails?, Harvard Business Review on Change, ed. ke-6 (Boston: Harvard Business Press, 1996), 1-21. 
halangan teknikal, halangan politik dan halangan berkaitan budaya $^{26}$.

Low dan Alfelor (2000) menjelaskan terdapat dua pendekatan terhadap keperluan atau klausa ISO 9000 iaitu pendekatan teknikal dan pendekatan bukan teknikal ataupun yang dikenali sebagai pendekatan gelagat $^{27}$. Para pengurus hendaklah memberi penekanan seimbang kepada kedua-dua pendekatan tersebut untuk memastikan sistem pengurusan kualiti ISO 9000 dapat dilaksanakan dengan lancar dan berkesan. Low dan Omar (1997) menyatakan bahawa tujuan pendekatan gelagat adalah untuk membangunkan persekitaran yang bersepadu untuk merangsang perubahan dan inovasi dengan matlamat utamanya untuk mencapai penambahbaikan atau peningkatan kualiti ${ }^{28}$.

Faktor insaniah dalam pengurusan kualiti berkait dengan aspek gelagat dan kebiasaannya berkaitan dengan 'aspek kemanusiaan' seperti latihan dan pendidikan, kesetiaan, kepimpinan, kerjasama, penghakupayaan (empowerment), fokus kepada pelanggan, penggunaan sumber manusia secara maksimum, hubungan dengan pembekal dan badan-badan profesional, komunikasi, ganjaran kepada prestasi dan sikap-sikap positif. Sebaliknya, aspek teknikal berkait dengan alat dan sistem dalam pengurusan kualiti iaitu penanda aras, sistem kualiti, penambahbaikan berterusan, inovasi, pengukuran prestasi, kawalan, fleksibiliti dan reka bentuk produk ${ }^{29}$.

Jelaslah bahawa faktor insaniah merupakan aspek penting dan perlu dikaji kerana peranannya sebagai pembantu atau perangsang kepada pelaksanaan ISO 9000 yang berkesan. Hanya pelaksanaan ISO 9000 yang berkesan akan membawa faedah yang banyak kepada organisasi. Dengan membuat analisa terhadap faktor-faktor

${ }^{26}$ Thomas G. Cummings, and Christpher G. Worley, Organization Development and Change, ed. ke-7 (United Kingdom: South-Western Publishing Collage Publishing, 2001).

${ }^{27}$ Sui Pheng Low dan Alfelor, W.M., Cross-Culture Influences on Quality Management System, Work Study 49, no.4 (2000), 134-144.

${ }^{28}$ Sui Pheng Low dan Omar, H.F., The Effective Maintenance of Quality Management Systems in the Construction Industry, International Journal of Quality and Reliability Management 14, no.8 (1997), 768-790.

${ }^{29}$ Winston G. Lewis, Kit Fai Pun, dan Terrence R.M Lalla, Empirical Investigation of the Hard and Soft Criteria of TQM in ISO 9001 Certified Small and Medium-Sized Enterprises, International Journal of Quality and Reliability Management 23, no.8 (2006), 964-985. 
insaniah, ia akan dapat membantu para penyelidik, pihak pengurusan dan pengamal pengurusan kualiti untuk memahami bagaimana dan mengapa manusia atau pekeja memberi reaksi berbeza kepada pelaksanaan ISO 9000. Contohnya, dengan menawarkan latihan, pengiktirafan dan ganjaran kepada eksekutif atau pekerja, akan menjadikan mereka lebih bermotivasi untuk melibatkan diri dan bekerjasama terhadap aktiviti-aktiviti berkaitan dengan pelaksanaan ISO 9000. Sebaliknya, kekurangan latihan dan ganjaran akan membuatkan pekerja mengelakkan diri daripada melibatkan diri program-program sistem kualiti. Tidak kurang penting juga, memahami faktor insaniah akan membantu para pengurus untuk mengatasi penolakan eksekutif dan pekerja terhadap ISO 9000.

\section{Integrasi Faktor Insaniah dalam Pelaksanaan ISO 9000}

Bahagian ini membincangkan faktor-faktor insaniah yang diintegrasikan ke dalam pelaksanaan ISO 9000. Terdapat enam faktor insaniah yang diintegrasikan iaitu kepimpinan, latihan dan pendidikan, kerjasama, fokus kepada pelanggan, ganjaran dan faktor terakhir ialah komunikasi. Integrasi keenam-enam faktor insaniah tersebut turut disorot daripada perspektif Islam sebagaimana yang dibincangkan seperti yang berikut:

\section{Kepimpinan}

Kepimpinan yang merupakan prinsip utama dalam pengurusan kualiti menekankan tentang kebolehan pemimpin atau pengurus tertinggi organisasi untuk membawa bersama-sama seluruh ahli organisasi secara sukarela ke arah pencapaian objektif kualiti yang telah ditetapkan. Perkataan 'sukarela' membawa makna bahawa pemimpin organisasi tidak boleh menggunakan kaedah paksaan kepada eksekutif dan pekerja untuk sama-sama terlibat dalam program kualiti. Sebaliknya, pemimpin perlu menggunakan kaedah yang betul untuk mendapatkan kerjasama semua pihak dalam usaha untuk menjayakan program kualiti.

Oleh kerana program ISO 9000 memerlukan perbelanjaan yang besar, maka amatlah penting untuk para pengurus menunjukkan komitmen mereka terlebih dahulu. Misalnya dengan memperuntukkan perbelanjaan menjalankan latihan berkaitan ISO 9000 seperti latihan kefahaman terhadap ISO 9000, audit, 
pembangunan prosedur kerja dan penambahbaikan berterusan. Pelaksanaan ISO 9000 juga memerlukan kemudahan dan peralatan tertentu seperti sistem fail yang canggih, susun atur pejabat yang selesa, kemudahan fizikal yang lengkap dan mesin pejabat secukupnya. Keperluan-keperluan ini perlu dipenuhi oleh pengurusan organisasi dengan menyediakan peruntukan secukupnya. Selain itu, pelaksanaan ISO 9000 melibatkan tugasan yang banyak dan berulang-ulang, dan ini sudah pastinya memberi tekanan kepada warga kerja. Dalam keadaan ini, amat penting untuk pemimpin organisasi memberi ganjaran dan penghargaan yang yang sewajarnya kepada mereka.

Para pengurus juga perlu menunjukkan kepimpinan terutamanya dalam aspek pemantauan terhadap pelaksanaan ISO 9000. Misalnya dengan membuat pemantauan terhadap kepatuhan warga kerja terhadap prosedur kerja yang telah ditetapkan. Pengurus juga perlu membuat semakan untuk melihat sama ada objektif kualiti telah dicapai ataupun belum. Sekiranya terdapat objektif kualiti yang tidak tercapai, pengurus perlu mencari puncanya. Punca kegagalan pencapaian objektif kualiti perlu diselidiki, sama ada ianya berpunca daripada sikap pekerja, pegawai, persekitaran ataupun ciri objektif kualiti itu sendiri yang terlalu tinggi.

Senario hari ini, melihat banyak penekanan telah ditujukan kepada sektor awam mahupun swasta agar organisasi pentadbiran dapat mencapai kecemerlangan, misalnya melalui program inovasi. Dalam konteks ini, pemimpin organisasi perlu mencari jalan agar program ISO 9000 tidak terhenti setakat pensjilan, tetapi dilanjutkan kepada program melalui mekanisme penambahbaikan selepas audit yang dijalankan setiap masa. Ini kerana proses penambahbaikan berterusan mampu merangsang inovasi, seterusnya mendorong kepada pencapaian organisasi yang cemerlang.

Islam amat mementingkan aspek kepimpinan. Hal ini dapat dilihat daripada hadis-hadis Rasulullah SAW seperti berikut:

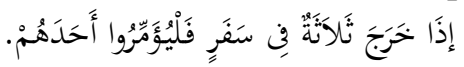


Terjemahan: "Apabila tiga bermusafir maka hendaklah salah seorang mengetuai". 30

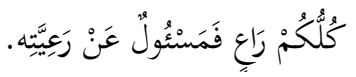

Terjemahan: "Abdullah bin Umar, dia berkata: Rasulullah SAW bersabda "Kalian semua adalah pemimpin dan bertanggungjawab terhadap rakyat yang dipimpinnya". ${ }^{31}$

Satu aspek penting peranan kepimpinan adalah meletakkan objektif, visi dan misi organisasi. Dalam konteks perlaksanaan ISO 9000, pemimpin bukan hanya perlu memberi fokus untuk memenuhi kehendak pelanggan. Tetapi lebih jauh daripada itu, Islam turut menekankan visi unggul iaitu untuk mencapai keredhaan Allah SWT. Oleh itu, selain pelanggan, pemimpin juga perlu untuk meletakkan kepentingan masyarakat sekeliling dan alam sekitar dalam menentukan objektif kualiti. Manakala itu, visi organisasi bukan hanya perlu untuk mencapai kecemerlangan pengurusan, tetapi juga untuk mencapai kebahagiaan dan balasan baik di akhirat nanti. Paradigma kepimpinan yang berorientasikan akhirat ini penting untuk difahamkan kepada seluruh warga kerja agar ianya menjadi pegangan dalam menjalankan tugas-tugas pentadbiran, termasuklah yang berkaitan dengan program kualiti. Pegangan yang teguh kepada agama mampu mencetuskan inspirasi kepada warga kerja untuk berusaha bersungguh-sungguh dan amanah. Selain itu, ia juga mampu menjadi benteng kepada warga kerja untuk menahan diri mereka daripada berbuat salah laku dan pecah amanah.

Kepimpinan yang bagus dalam sesebuah organisasi juga mampu merangsang produktiviti pekerja. Ia juga mampu mewujudkan suasana harmoni dan budaya musyawarah, yang selari dengan kehendak Islam. Pemimpin organisasi hendaklah memastikan bahawa pelaksanaan piawaian ISO 9000 bertepatan dengan kehendak Islam, misalnya dengan menyediakan produk atau perkhidmatan Halal. Selain itu, keperluan pekerja dan pejabat hendaklah dipenuhi kerana pelaksanaan ISO 9000 memerlukan sumber mencukupi. Kebajikan pekerja juga perlu diberi perhatian

${ }^{30}$ Sunan Abu Daud, Kitāb al-Jihād, Bāb fī al-Qaumī Yusāfiruna wa Yuammirunā Ahaduhum, no. hadith 2608 (Riyadh: Darusslam, 2000).

${ }^{31}$ Șahīh al-Bukhārī, Kitāb al-Itqun, Bāb al-'Abd Rain fì Mā lā Saidihi, no.hadith 2558 (Riyadh: Darussalam, 2000). 
kerana pengabaian kepada aspek tersebut akan mengganggu komitmen pekerja terhadap pelaksanaan ISO 9000.

\section{Latihan dan Pendidikan}

Pembangunan dan pelaksanaan ISO 9000 memerlukan kefahaman yang mendalam dalam kalangan seluruh ahli organisasi. ISO 9000 bukan hanya memerlukan kefahaman asas seperti kefahaman terhadap klausa-klausanya, pembangunan dan pelaksanaan prosedur kerja. Tetapi ianya juga memerlukan kefahaman terhadap perkara-perkara yang lebih jauh lagi iaitu memahami kaedah atau cara piawaian ISO 9000 boleh meningkatkan produktiviti, cara untuk menyuburkan budaya kualiti dan kaedah perlaksanaan ISO 9000 yang mampu meningkatkan keberkesanan pengurusan seterusnya membawa organisasi kepada kecemerlangan. Oleh itu, pelbagai corak latihan mesti diberikan seperti latihan kefahaman terhadap ISO 9000, pembangunan prosedur, audit, statistik, penambahbaikan berterusan, budaya kualiti, produktiviti dan inovasi. berikut:

Kepentingan ilmu dalam Islam dapat dilihat daripada hadis

$$
\text { من سلك طريقا يطلب فيه علما سلك الله به طريقا من الجنة }
$$

Terjemahan: "Sesiapa yang menempuh satu jalan kerana mencari ilmu, maka Allah akan memudahkan baginya jalan ke syurga". ${ }^{32}$

Al-Qur'an juga dengan jelas menggambarkan tentang darjat orang-orang yang berilmu seperti dalam ayat berikut:

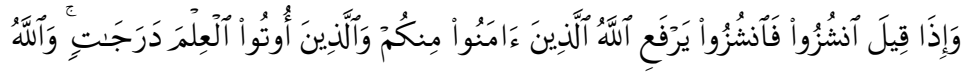

$$
\begin{aligned}
& \text { بِمَا تَعْمَلُونَ خَبِير }
\end{aligned}
$$

Al-Mujādalah 58:11

Terjemahan: Niscaya Allah akan meninggikan orang-orang yang beriman di antaramu dan orang-orang yang diberi ilmu pengetahuan beberapa darjat. Dan Allah Maha Mengetahui apa yang kamu kerjakan.

Ilmu hanya dapat diperolehi melalui proses latihan dan pendidikan. Dalam konteks pelaksanaan ISO 9000, proses tersebut

${ }^{32}$ Sunan Abu Daud, Kitab al-'Ilm, Bab fî Faḍl al-'Ilm, no. Hadith 3641 (Riyadh: Darussalam, 2000) 
perlu dilaksanakan secara berterusan. Selain aspek teknikal, latihan berkenaan dengan pelaksanaan ISO 9000 hendaklah juga memberi penekanan kepada aspek-aspek kemanusiaan, keagamaan dan spiritualiti. Hal ini kerana latihan yang hanya mementingkan aspek teknikal akan hanya meningkatkan kecekapan kemahiran pekerja sahaja, tetapi tidak kepada aspek insaniah. Perkara sebegini boleh menjejaskan kelancaran pelaksanaan ISO 9000 kerana ia bukan hanya bergantung kepada perkara teknikal, tetapi juga perkara yang berkait dengan sifat-sifat mulia iaitu sabar, ikhlas, tabah, gigih dan berdisiplin dalam bekerja. Sifat-sifat mulia ini hanya dapat dipupuk melalui latihan kerohanian seperti tazkirah, doa, zikir, puasa sunat dan solat sunat. Amalan sifat-sifat mulia dalam kalangan warga kerja akan membawa kesan positif serta memacu pelaksanaan sistem pengurusan kualiti ISO 9000 ke arah kecemerlangan.

\section{Kerjasama}

Pelaksanaan ISO 9000 memerlukan kerjasama yang erat kerana ia melibatkan tugasan yang banyak dan berulang-ulang. Kerjasama ini boleh diperlukan dalam tiga peringkat pelaksanaan ISO 9000 iaitu peringkat pembangunan, pelaksanaan dan penambahbaikan. Peringkat pertama ialah peringkat pembangunan iaitu peringkat permulaan yang melibatkan kerja-kerja pendokumentasian segala gerak kerja. Peringkat ini melibatkan pembangunan prosedur kerja iaitu segala proses dan gerak kerja perlu dibuat dalam bentuk prosedur dan kemudiannya didokumenkan. Pada peringkat ini, kerja-kerja yang rumit perlu dilakukan seperti mengenal pasti kesemua gerak kerja dan perinciannya. Kemudian, gerak kerja perlu dipecahkan kepada beberapa peringkat proses kerja dan perincian tersebut perlu ditulis dengan jelas agar prosedur kerja yang dihasilkan dapat menggambarkan proses kerja sebenar. Proses kerja yang jelas akan membantu kefahaman yang pantas disebabkan ciri ini penting untuk menjamin kelancaran pelaksanaan ISO 9000. Kerja-kerja yang rumit ini memerlukan kerjasama semua pihak daripada peringkat atasan sehingga kepada staf sokongan kerana ia melibatkan proses kerja secara menyeluruh.

Seterusnya ialah peringkat pelaksanaan ISO 9000. Pada peringkat ini, komitmen juga diperlukan untuk mematuhi prosedur 
kerja yang telah dibangunkan. Aspek ini merupakan keperluan asas pelaksanaan ISO 9000 yang perlu dipatuhi. Kegagalan mematuhi prosedur kerja terutamanya yang melibatkan prosedur utama akan menjejaskan kualiti produk atau perkhidmatan yang disediakan untuk pelanggan atau pengguna. Selain itu, komitmen semua pihak diperlukan kerana setiap proses kerja yang dilaksanakan mempunyai kaitan antara satu sama lain. Dalam konteks ini, kerjasama semua pihak diperlukan kerana pelaksanaan ISO 9000 perlu dilakukan secara menyeluruh. Kemudian, peringkat terakhir ialah peringkat kerja-kerja penambahbaikan yang dilakukan hasil penemuan daripada audit dalaman atau luaran. Hasil penemuan audit mendedahkan aspek kekuatan pelaksanaan ISO 9000. Selain itu, hasil audit juga mendedahkan aspek kelompangan dan kelemahan yang perlu dibaikki. Misalnya, ketidakpatuhan kepada prosedur kerja, kegagalan memenuhi kehendak pelanggan, persekitaran kerja tidak kondusif dan komunikasi kurang lancar. Kelemahan-kelemahan ini perlu diperbaiki dan tanggungjawab ini memerlukan kerjasama semua pihak.

Dalam Islam, kerjasama atau dikenali sebagai Syurā merupakan antara perkara yang diberi keutamaan. Allah Taala berfirman yang bermaksud:
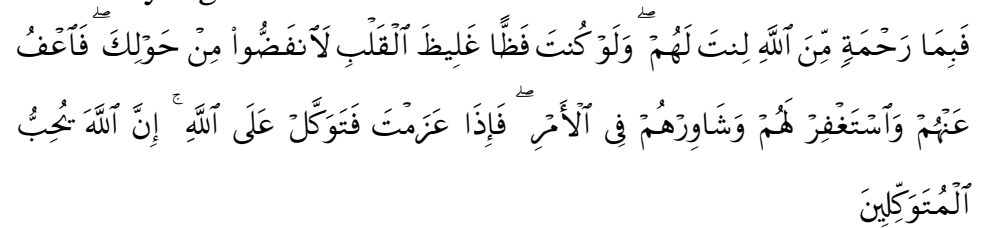

Āli-‘Imrān 3:159

Terjemahan: Maka dengan sebab rahmat (yang melimpahlimpah) dari Allah (kepadamu wahai Muhammad), engkau telah bersikap lemah-lembut kepada mereka (sahabat-sahabat dan pengikutmu), dan kalaulah engkau bersikap kasar lagi keras hati, tentulah mereka lari dari kelilingmu. Oleh itu maafkanlah mereka (mengenai kesalahan yang mereka lakukan terhadapmu), dan pohonkanlah ampun bagi mereka, dan juga bermesyuaratlah dengan mereka dalam urusan (peperangan dan hal-hal keduniaan) itu. Kemudian apabila engkau telah berazam (sesudah bermesyuarat, untuk membuat 
sesuatu) maka bertawakalah kepada Allah, sesungguhnya Allah Mengasihi orang-orang yang bertawakal kepadaNya.

Firman Allah Taala lagi yang bermaksud:

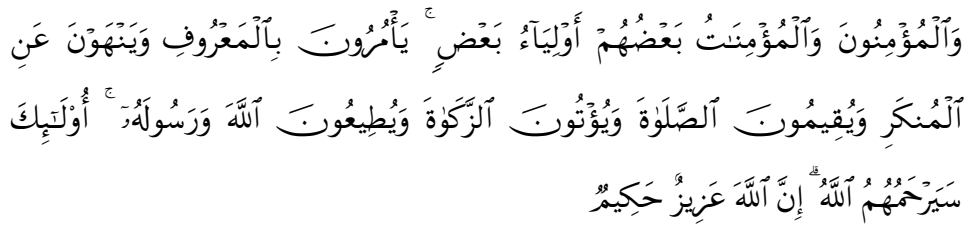

Al-Tawbah 9:71

Terjemahan: "Dan orang-orang yang beriman lelaki dan perempuan, setengahnya menjadi penolong bagi setengah yang lain, mereka menyuruh berbuat kebaikan dan melarang daripada berbuat kejahatan dan mereka mendirikan sembahyang dan memberi zakat serta taat kepada Allah dan RasulNya. Mereka itu akan diberi rahmat oleh Allah".

Pelaksanaan ISO 9000 yang melibatkan kerja yang banyak dan kompleks memerlukan kerjasama erat semua pihak. Kerjasama erat, misalnya melalui proses perbincangan akan membuahkan idea yang baik untuk menyelesaikan setiap permasalahan yang timbul. Hal ini selari dengan konsep Syurā yang dianjurkan oleh Islam. Perbincangan atau Syurā yang diamalkan bukan sahaja penting untuk mencari idea, tetapi ia juga mekanisme untuk menjana motivasi dalam kalangan pekerja. Pegawai dan pekerja yang diajak berbincang akan merasakan diri mereka lebih dihargai kerana turut dilibatkan untuk memberi input dalam proses penyelesaian masalah. Ini menjadikan mereka lebih bertanggungjawab terhadap tugasan yang diberikan.

\section{Fokus Kepada Pelanggan}

Pelanggan merupakan komponen dan sasaran utama bagi setiap pelaksanaan sistem pengurusan kualiti, termasuklah pelaksanaan ISO 9000. Langkah awal kepada pelaksanaan ISO 9000 adalah dengan mengenal pasti kehendak pelanggan, dan kemudiannya mekanisme perlu dibangunkan untuk memenuhi kehendak tersebut. Bagi sektor swasta, pelanggan biasanya membayar sepenuhnya ke atas barangan atau perkhidmatan yang diperoleh. Manakala di sektor awam pula, pelanggan mendapatkan perkhidmatan yang disediakan oleh kerajaan secara percuma. Kedua-dua jenis pelanggan dari sektor swasta mahupun sektor 
awam ini walaupun berbeza dari segi cara perolehan ke atas perkhidmatan, tetapi kedua-duanya berhak mendapatkan perkhidmatan yang berkualiti tinggi.

Dengan peningkatan pendidikan dan taraf hidup bagi kebanyakan rakyat Malaysia masa kini, para pelanggan lebih bersifat kritikal dan meletakkan jangkaan yang tinggi terhadap kualiti perkhidmatan. Oleh itu, menjadi kewajipan setiap organisasi untuk menumpukan segala usaha dan sumber agar produk atau perkhidmatan yang ditawarkan mampu memenuhi jangkaan tersebut. Justeru, warga kerja hendaklah komited untuk mematuhi prosedur dan aliran kerja yang telah ditetapkan. Selain itu, langkah-langkah penambahbaikan hendaklah dititikberatkan agar kualiti perkhidmatan dapat dipertahankan dan seterusnya ditingkatkan.

Dalam melaksanakan ISO 9000, saluran komunikasi untuk pelanggan perlu disediakan agar segala komen dan pendapat mereka dapat diketahui. Dalam zaman kemajuan ICT pada hari ini, saluran komunikasi secara talian perlu dimaksimakan sebaik mungkin kerana ia akan mempengaruhi sejauh mana pantasnya organisasi bertindak balas terhadap komen pelanggan atau pengguna. Darjah kepantasan seperti ini pada masa kini menjadi kayu ukur untuk menilai sejauh mana berkesannya pengurusan sebuah organisasi. Pengurusan organisasi hendaklah bersikap telus dalam mengurus komen dan aduan pelanggan, misalnya dengan memberitahu langkah-langkah yang diambil terhadap aduan tersebut dan disertakan dengan sasaran masa untuk menyelesaikannya. Selain itu, perkara-perkara penting seperti kualiti produk, spefikasi dan harga hendaklah dinyatakan dengan jelas dan tidak dimanipulasi.

Kerja yang bersungguh-sungguh untuk menghasilkan produk dan perkhidmatan berkualiti tinggi adalah selari dengan kehendak Islam. Hal ini demikian kerana ia adalah penting untuk menjamin kepentingan dan kebajikan pelanggan atau pengguna. Malahan, Islam juga mementingkan penambahbaikan berterusan kerana hanya dengan kaedah ini kualiti perkhidmatan dapat ditingkatkan untuk menuju ke arah kecemerlangan. Penambahbaikan berterusan ini adalah selari dengan konsep istiqamah iaitu melakukan perkara-perkara baik secara berterusan dengan sasaran utamanya untuk menghasilkan Islah atau perubahan sebenar. Tambahan lagi, 
konsep meraikan komen pelanggan dan bersikap telus juga adalah selari dengan kehendak Islam yang mementingkan amanah dalam segenap aspek kehidupan. Firman Allah Taala yang bermaksud:

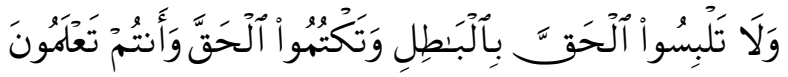

Al-Baqarah 2:42

Terjemahan: Dan janganlah kamu campur adukkan yang benar itu dengan yang salah, dan kamu sembunyikan yang benar itu pula padahal kamu semua mengetahuinya.

Amanah dalam pelaksanaan ISO 9000 bukan hanya berkait rapat dengan layanan terhadap komen pelanggan, tetapi juga merujuk kepada larangan menipu timbangan terhadap pelanggan. Firman Allah Taala yang bermaksud:

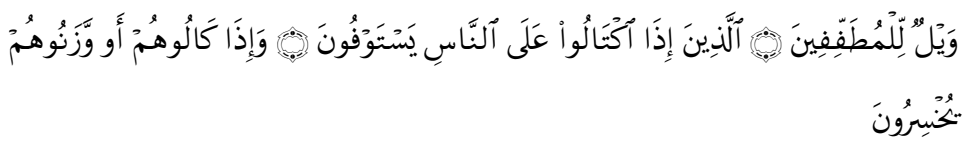

Al-Muțaffifin 83:1-3

Terjemahan: Kecelakaan besar bagi orang-orang yang curang (dalam timbangan dan sukatan), Iaitu mereka yang apabila menerima sukatan (gantang cupak) dari orang lain mereka mengambilnya dengan cukup, dan (sebaliknya) apabila mereka menyukat atau menimbang untuk orang lain, mereka kurangi.

Amanah juga perlu untuk menahan diri daripada melakukan rasuah, kerana rasuah merupakan perbuatan yang dilarang dalam Islam. Hal ini ditegaskan dalam hadis Nabi SAW seperti berikut:

$$
\text { لَعْنَة اللَّهِ عَلَى الرََّاشِي وَالْهُرْتَشِ }
$$

Terjemahan: "Allah SWT melaknat pemberi rasuah dan penerima rasuah". ${ }^{33}$

Selain itu, walaupun memenuhi kepuasan pelanggan merupakan agenda utama pelaksanaan ISO 9000, namun hendaklah dipastikan agar organisasi tidak mengeluarkan barangan yang memudaratkan pelanggan, seperti penjualan minuman beralkohol.

${ }^{33}$ Hadith Riwayat al-Tirmidhī, kitab al-Aḥkām, bāb Mā Jā fì al-Rayi wa alMurtasyi fì al-Hukmi, no. hadith 1336 (Riyadh: Darussalam, 2000). 


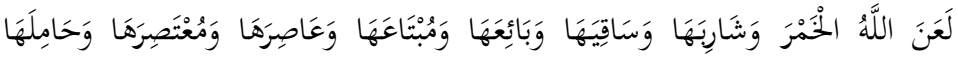 وَالْمَحْمُولَةَ إلَنْْ}

Terjemahan: "Allah melaknat arak, peminum, penghidang, penjual, pembeli, pemerah, meminta agar ia diperah, pembawanya dan orang yang ia dibawa kepadanya". ${ }^{34}$

Selain itu, perkhidmatan yang melalaikan seperti pusat perjudian dan rumah urut juga tidak wajar ditawarkan kepada pelanggan. Firman Allah Taala yang bermaksud:

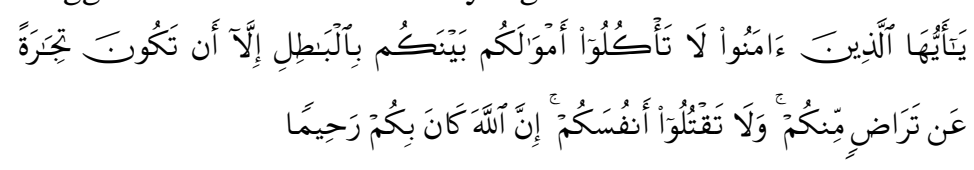

Al-Nisā' 4:29

Terjemahan: Wahai orang-orang yang beriman, janganlah kamu makan (gunakan) harta-harta kamu sesama kamu dengan jalan yang salah (tipu, judi dan sebagainya), kecuali dengan jalan perniagaan yang dilakukan secara suka sama suka di antara kamu, dan janganlah kamu berbunuh-bunuhan sesama sendiri. Sesungguhnya Allah sentiasa mengasihani kamu.

Kesimpulannya ialah kepuasan pelanggan merupakan aspek utama yang perlu diberi perhatian dalam perlaksanaan ISO 9000. Perkara ini selari dengan kehendak Islam yang menekankan layanan baik kepada semua pihak. Namun begitu, perlu juga diberi perhatian bahawa kehendak pelanggan yang tidak selari dengan kehendak Islam hendaklah diabaikan kerana ianya akan menyebabkan kemudaratan.

\section{Ganjaran}

Pelaksanaan ISO 9000 memerlukan sumbangan dan penglibatan yang maksima daripada seluruh warga kerja. Pelaksanaan ISO 9000 boleh dibahagikan kepada tiga peringkat utama iaitu peringkat pembangunan sistem pengurusan kualiti, peringkat pelaksanaan, dan peringkat penambahbaikan berterusan dan kecemerlangan. Kesemua peringkat tersebut melibatkan kerjakerja yang sering berulang, pelaksanaan prosedur kerja, audit,

\footnotetext{
${ }^{34}$ Hadith Riwayat Sunan Abī Daud, kitab al-'Asyribah, bab 'Āsir wa al-Khamru, no. hadith 3674 (Riyadh: Darussalam, 2000).
} 
penambahbaikan dan inovasi. Kepelbagaian tugas yang bersifat kompleks tersebut menuntut tenaga yang bukan sedikit daripada semua warga kerja. Oleh itu, amatlah wajar sumbangan warga kerja diberi pengiktirafan dan penghargaan yang sebaik-baiknya. Misalnya, sumbangan pegawai dan pekerja yang banyak melibatkan diri dalam program kualiti hendaklah dikira secara signifikan dalam penilaian prestasi tahunan.

Ganjaran juga bukan hanya yang bersifat jangka panjang, tetapi juga yang bersifat jangka pendek. Ini kerana keyakinan dan motivasi para pegawai dan pekerja terhadap pelaksanaan ISO 9000 sebenarnya terbina secara berperingkat, dan bukan secara mendadak. Oleh itu, ganjaran jangka pendek seperti sijil pelantikan, surat penghargaan dan pemberian cenderahati boleh diberi tahunan. Penghargaan jangka pendek juga termasuklah anugerah pekerja cemerlang, hari keluarga dan jamuan makan tahunan. Manakala ganjaran jangka panjang boleh diberikan dalam bentuk kenaikan pangkat, perlantikan untuk mengetuai unit-unit tertentu, tawaran latihan dan hadiah melanjutkan pengajian. Ganjaran yang diberikan bukan hanya bersifat kewangan, tetapi juga bersifat bukan kewangan seperti surat penghargaan, kata-kata motivasi, kemudahan kesihatan dan aspek kebajikan.

Pemberian pengiktirafan dan ganjaran kepada golongan pekerja adalah selari dengan kehendak Islam. Hal ini seperti yang ditegaskan antaranya dalam hadis Nabi SAW yang bermaksud:

Terjemahan: "Berikan sebahagian dari hasil usaha buruh kepadanya kerana tiada pekerja yang pulang tanpa ganjaran". 35

Lagi hadis Nabi SAW yang bermaksud:

$$
\text { أعطوا الأجير أجره قبل أن يجف عرقه }
$$

Terjemahan: "Berilah upah kepada orang yang mengambil upah sebelum kering peluhnya". ${ }^{36}$

Memberi ganjaran kepada warga kerja sebenarnya sama seperti memberi pertolongan kepada mereka. Sesungguhnya,

${ }^{35}$ Musnad Ahmad, dipetik oleh Afzal-Ur-Rahman. Doktrin Ekonomi Islam. Terj. Zaharah Salleh (Kuala Lumpur: DBP, 1991), 2:299

${ }^{36}$ Hadis Riwayat Ibnu Majah. Lihat Ibn Hajar al-'Asqalān̄̄, Kitab Bulughul Maram, Bab al-Musaqah wal ijārah, no. hadith 938 (Riyadh: Darussalam. 2000). 
setiap pertolongan yang diberikan akan mendapat balasan baik. Firman Allah dalam surah an-Nisā':

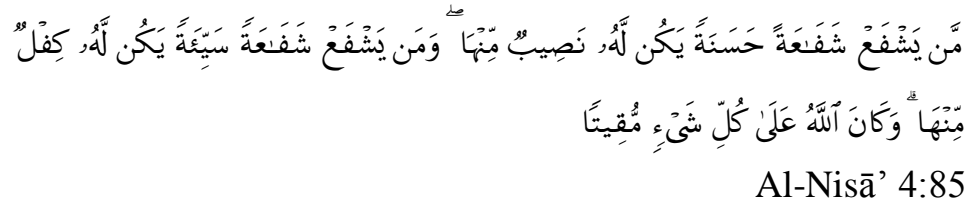

Terjemahan: Setiap yang memberi syafaat yang baik nescaya ia akan memperolehi bahagian (pahala) daripadanya dan sesiapa yang memberikan syafaat yang buruk nescaya ia akan mendapat bahagian (dosa) daripadanya dan ingatlah Allah Maha Kuasa atas tiap-tiap sesuatu.

Pemberian ganjaran kepada pekerja akan membuahkan perasaan dihargai dan ini akan menyuntik motivasi untuk bekerja dengan lebih gigih demi kelangsungan perlaksanaan ISO 9000 yang efektif. Apatah lagi dengan peningkatan kos hidup yang ketara pada masa kini, pemberian ganjaran yang berbentuk kewangan menjadi sangat bermakna kerana ia mampu meringankan beban yang ditanggung golongan pegawai dan pekerja. Islam juga menyuruh agar upah dan ganjaran diberi dengan segera. Kesegeraan memberi upah ini penting kerana pekerja mempunyai keperluan yang pelbagai dan kompleks sifatnya. Misalnya dalam konteks masa kini, kenaikan harga barang bermakna golongan pekerja perlu mempunyai wang yang mencukupi untuk mereka memberi barangan untuk kegunaan seharian. Bagi golongan pekerja sokongan, ganjaran berbentuk kewangan adalah lebih penting daripada ganjaran berbentuk percutian. Bagi warga kerja peringkat pegawai pula, surat penghargaan dan kenaikan pangkat pula menjadi isu penting. Kenaikan pangkat misalnya akan memberi kepuasan kepada mereka. Ia juga memberi petunjuk dan keyakinan bahawa mereka mempunyai peluang untuk membangunkan kerjaya masingmasing.

Ganjaran yang diberikan mampu membina hubungan harmoni antara majikan dan pekerja, di samping memupuk kesetiaan kepada organisasi. Pegawai dan pekerja yang setia menjadi aset penting kerana kecekapan mereka yang semakin meningkat sangat berguna dalam memastikan sistem pengurusan kualiti dapat diteruskan dengan jayanya. 


\section{Komunikasi}

Oleh kerana piawaian ISO 9000 melibatkan perincian dan bersifat kompleks, maka komunikasi berkesan amat diperlukan bagi memastikan perlaksanaannya berjalan lancar. Perlaksanaan ISO 9000 banyak melibatkan pelbagai prosedur dan arahan kerja yang mesti dipatuhi, serta melibatkan semua pihak. Misalnya, pihak atasan dan pengurusan perlu selalu mengingatkan warga kerja untuk mematuhi prosedur kerja kerana ia memerlukan keperluan asas dalam pelaksanaan ISO 9000. Dalam hal ini, ayat-ayat perintah perlu dielakkan, sebaliknya komunikasi berkesan hendaklah digunakan kerana warga kerja juga perlu dihormati perasaan mereka. Selain itu, objektif-objektif kualiti yang ditetapkan dalam pelaksanaan ISO 9000 memerlukan komitmen tinggi semua pihak untuk mencapainya. Dalam hal inilah, pihak pengurusan perlu bijak berkomunikasi dan memotivasikan warga kerja supaya mereka dapat berganding bahu untuk mencapai objektif-objektif kualiti yang disasarkan.

Tidak kurang penting juga ialah komunikasi terhadap golongan profesional yang perlu diberi perhatian. Golongan profesional seperti pensyarah, akauntan, doktor dan peguam mempunyai cara dan budaya kerja mereka yang tersendiri. Pensyarah misalnya adalah golongan yang mementingkan kebebasan akademik dan berfikir, manakala pelaksanaan ISO 9000 memerlukan kepatuhan kepada prosedur kerja. Tetapi ini tidak bermakna pensyarah tidak akan mematuhi prosedur kerja, tetapi input mereka perlu diambilkira semasa proses pembangunan prosedur kerja dilakukan. Selain itu, perlu juga dipastikan prosedur kerja dan perlaksanaan ISO 9000 tidak menjadi penghalang kepada pembangunan kerjaya mereka. Jika keperluan ini dapat dipenuhi, sudah pasti para pensyarah atau golongan akademik ini akan memberi kerjasama jitu dalam program ISO 9000 yang dilaksanakan.

Komunikasi berkesan dengan pihak berkepentingan juga perlu diberi perhatian, misalnya komunikasi dengan pihak pembekal. Pihak pembekal memainkan peranan yang penting kerana mereka membekalkan bahan atau perkhidmatan yang diperlukan untuk menghasilkan output akhir organisasi. Kualiti bahan atau perkhidmatan yang diberi oleh pembekal akan mempengaruhi kualiti output organisasi. Oleh itu, amatlah penting 
untuk pengurus organisasi menjelaskan dengan tepat spesifikasi bahan dan perkhidmatan yang disediakan oleh pembekal. Komunikasi yang tepat, tegas dan berkesan akan memberi petunjuk kepada syarikat pembekal bahawa kualiti bahan dan perkhidmatan yang dibekalkan mestilah memenuhi spesifikasi yang telah ditetapkan.

Islam mengajar agar berkomunikasi dengan cara yang berhemah dan bijaksana agar mesej yang ingin disampaikan dapat diterima oleh pihak yang disasarkan. Hal ini seperti yang digambarkan hadis dan ayat al-Qur' an yang berikut:

Hadis Nabi SAW yang bermaksud:

$$
\text { حدثوا الناس بما يعرفون }
$$

Terjemahan: "Berbicaralah kepada manusia sesuai dengan kadar akal mereka". ${ }^{37}$

Penegasan dari ayat suci al-Qur'an menerusi surah an-Nahl:

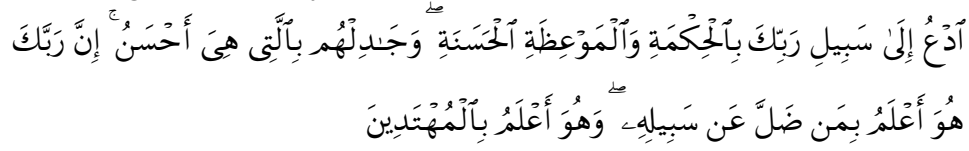

Al-Nahl 16:125

Terjemahan: Serulah ke jalan Tuhanmu (wahai Muhammad) dengan hikmat kebijaksanaan dan nasihat pengajaran yang baik, dan berbahaslah dengan mereka (yang engkau serukan itu) dengan cara yang lebih baik; sesungguhnya Tuhanmu Dia lah jua yang lebih mengetahui akan orang yang sesat dari jalanNya, dan Dia lah jua yang lebih mengetahui akan orangorang yang mendapat hidayah petunjuk.

Komunikasi berkesan yang dipentingkan dalam pelaksanaan ISO 9000 adalah selari dengan kehendak Islam. Dalam konteks pelaksanaan ISO 9000, komunikasi berkesan menjadi perkara utama kerana ia akan mempengaruhi kelancaran segala gerak kerja. Apatah lagi dengan ciri pekerjaan masa kini yang pelbagai dan bersifat kompleks, tekanan kepada komunikasi berkesan semakin tinggi. Golongan warga kerja yang mempunyai ciri tertentu juga perlu difahami, agar komunikasi berkesan dapat diwujudkan. Golongan pekerja sokongan misalnya mungkin memerlukan arahan yang berulang kali untuk melakukan sesuatu

${ }^{37}$ Hadis Riwayat al-Bukhari, Kitab al-'Ilm, Bab Man Khassa bi al-'Ilmī Qawma Duna Karahiah an La Yafhamu, no. Hadith 127 (Riyadh: Darussalam, 2000). 
pekerjaan. Manakala golongan profesional berkemahiran tinggi seperti pensyarah dan doktor pula tidak suka ayat yang bersifat memerintah. Oleh itu, pihak pengurusan perlu menggunakan kaedah yang sesuai untuk golongan pekerja yang berlainan. Komunikasi dengan pekerja sokongan memerlukan kesabaran, manakala komunikasi dengan golongan profesional memerlukan diplomasi. Kaedah komunikasi yang mementingkan musyawarah, berhemah dan berdiplomasi misalnya, akan mewujudkan suasana warga kerja rasa dihargai dan dihormati. Fenomena ini akan menyuntik suasana harmoni dan motivasi dalam kalangan warga kerja. Warga kerja yang mempunyai motivasi lazimnya akan menunjukkan komitmen yang tinggi dalam melaksanakan aktivitiaktiviti pelaksanaan program ISO 9000.

Integrasi faktor-faktor insaniah ke dalam pelaksanaan ISO 9000 yang dibincangkan tadi dapat digambarkan seperti dalam Rajah 1 yang berikut: 


\section{Rajah 1: Model Integrasi Faktor Insaniah dalam Pelaksanaan ISO 9000 Dari Perspektif Islam}

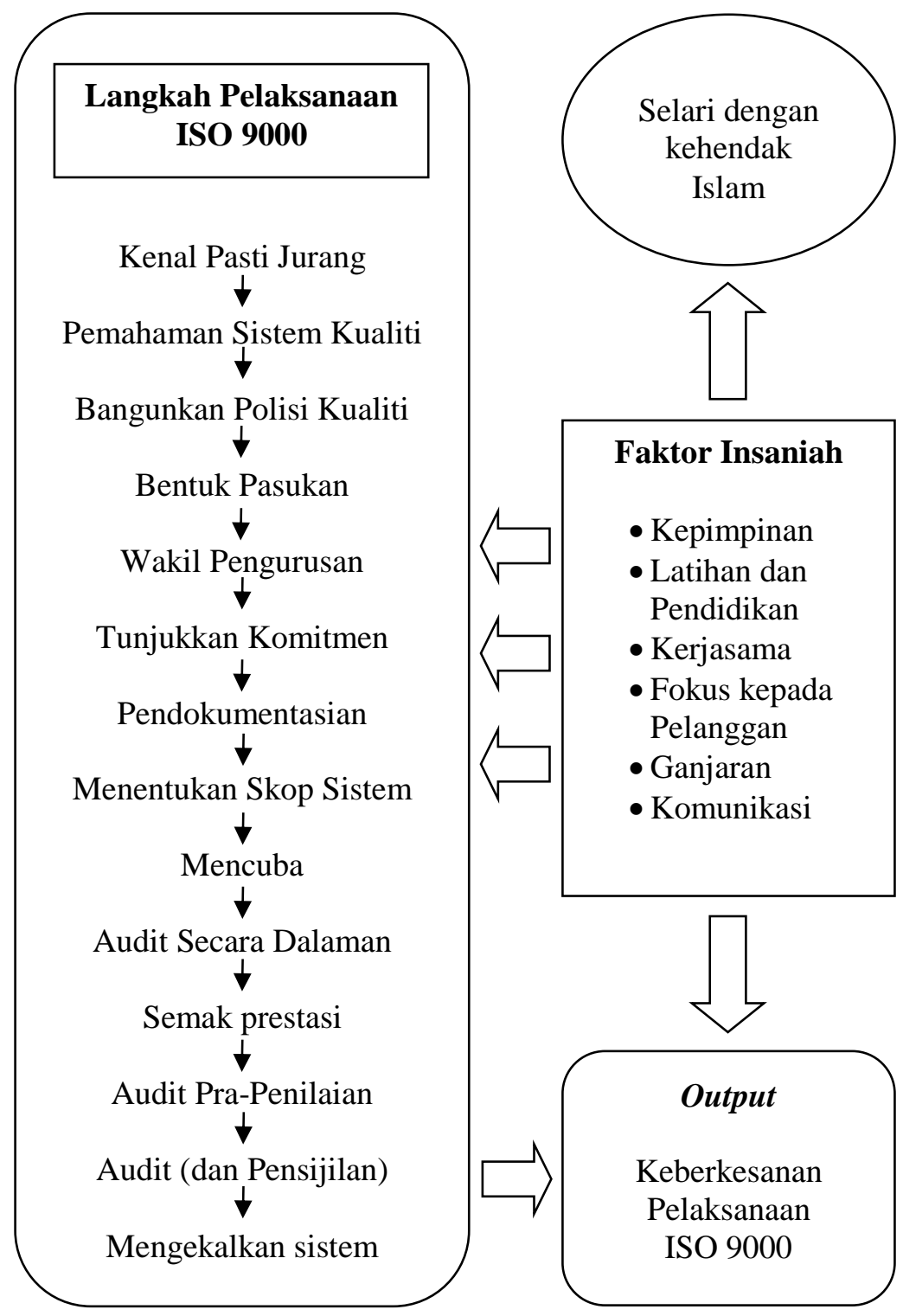

Sumber: Arni dan Ilhaamie, 2011. 
Rajah di atas menunjukkan pelaksanaan ISO 9000 mengandungi 14 langkah, yang bermula dengan langkah mengenal pasti jurang pengurusan sehinggalah kepada audit, pensijilan dan usaha-usaha untuk mempertahankan pensijilan. Pelaksanaan ISO 9000 pula diintegrasikan dengan enam faktor insaniah iaitu kepimpinan, latihan dan pendidikan, kerjasama, fokus kepada pelanggan, ganjaran dan komunikasi. Faktor-faktor insaniah tersebut memerlukan penyelarasan tertentu agar ianya selari dengan kehendak Islam yang mengambikira kepentingan pelbagai pihak. Integrasi faktor-faktor insaniah ke dalam pelaksanaan ISO 9000 akhirnya menghasilkan natijah positif iaitu pelaksanaan piawaian ISO 9000 yang berkesan.

\section{Penutup}

Secara tuntasnya pelaksanaan sistem pengurusan kualiti ISO 9000 yang didasari dan diintegrasikan dengan keenam-enam faktor insaniah tersebut dengan memenuhi keperluan atau kehendak Islam, pasti mendatangkan impak yang positif terhadap kecemerlangan sesebuah organisasi dan juga para pekerjanya. Malah kesannya bukan hanya setakat peningkatan luaran atau sekadar output yang bersifat materialistik sahaja, tetapi yang lebih penting memperoleh keberkatan daripada Allah SWT serta dapat menjamin kejayaan sebenar (al-Faläh) sama ada di dunia mahupun akhirat kelak.

Kepimpinan yang amanah, latihan yang menekankan aspek kerohanian dan semangat syura atau kerjasama mampu memantapkan lagi perlaksanaan ISO 9000 di mana-mana organisasi. Selain itu, usaha-usaha memenuhi tuntutan pelanggan yang tidak bertentangan dengan kehendak syariah pasti akan membawa kemaslahatan kepada pelanggan itu sendiri. Manakala aspek ganjaran yang mapan untuk warga organisasi akan meningkatkan motivasi kerja dalam kalangan mereka. Akhir sekali, komunikasi berkesan dan berhemah mampu membentuk suasana harmoni di antara pihak pengurusan dan pekerja. Kesemua faktor insaniah tersebut iaitu kepimpinan, latihan dan pendidikan, kerjasama, fokus kepada pelanggan, ganjaran dan komunikasi sebenarnya merupakan faktor pemangkin yang mampu meningkatkan keberkesanan perlaksanaan ISO 9000. Aspek ini merupakan perkara penting yang perlu diberi perhatian 
kerana dengan perlaksanaan ISO 9000 yang berkesan sahaja akan membawa pelbagai faedah dan kesan positif kepada seluruh warga organisasi.

Model ini akan menjadi panduan kepada mana-mana organisasi yang bercadang atau sedang melaksanakan ISO 9000 dalam usaha pihak pengurusan untuk meningkatkan keberkesanan perlaksanaannya. Model ini juga boleh digunakan oleh pihak pengurusan organisasi sebagai panduan tentang bagaimana seharusnya faktor-faktor insaniah yang disuntik dengan nilai-nilai Islam dapat diintegrasikan ke dalam perlaksanaan ISO 9000. Model-model perlaksanaan ISO 9000 sedia ada banyak dibangunkan berasaskan paradigm barat yang mementingkan aspek teknikal dan output sahaja. Maka, model yang dibangunkan dalam kajian ini mampu menjadi alternatif kepada para sarjana dan pengamal program kualiti kerana ianya dibangunkan berasaskan pandangan Islam lebih bersifat holistik serta memberi perhatian utama kepada aspek nilai dan kerohanian.

\section{Bibliografi}

Beckford, J. Quality. Ed. ke-2. London: Routledge, 2000.

Bendell, T. The Implications of the Changes to ISO 9000 for Organisational Excellence. Measuring Business Excellence 4, no.3 (2000):11-14.

Bhatti M.I. and Awan, H.M. An Evaluation of ISO 9000 Registration Practices. Managerial Finance, 29 no.7 (2003): 109-134.

Bhuiyan, N. and Alam, N., 2005. A Case Study of Quality System Implementation in a Small Manufacturing Firm. International Journal of Productivity Management 54 no.3 (2005): 172-186.

Bhuiyan, N. and Alam, N., ISO 9001:2000 Implementation. International Journal of Productivity and Performance Management 53, no. 1 (2004), 10-17.

Cummings, T.G. and Worley, C.G., Organization Development and Change. Ed. ke-7. United Kingdom: South-Western Publishing College Publishing, 2001.

Dale, B.G., Managing Quality. Ed.ke-3. London: Blackwell Publishers, 2003.

Ibn Ḥajar, Abū al-Fạ̣l Aḥmad bin 'Alī bin Muḥammad al'Asqalānī. Bulugh al-Maram. Riyadh: Darussalam, 2000. 
Hoyle, D. ISO 9000:2000 (electronic resources): A-Z guide. Oxford: Butterworth Heinemann, 2003.

Hoyle, D. ISO 9000 Quality Systems Handbook. Ed.ke-4. Oxford: Butterworth Heinemann, 2001.

ISO Standard. Quality Management System (QMS) Requirements, International Organization for Standardization, Geneva, 2005.

ISO Standard, ISO 9000 - Quality management. Retrieved September 5, 2014, from http://www.iso.org/iso/home/standards /management-standards/iso_9000.htm, Geneva, 2014.

ISO Standard. Executive summary, The ISO survey of management system standard Certifications -2013 . Retrieved January $3^{\text {rd }}$, 2015, from http://www.iso.org/iso/iso_survey_executivesummary.pdf?v2013, Geneva 2015.

Kehoe, D.F. The Fundamentals of Quality Management. London: Chapman Hall, 1996.

Kotter, J.P. Leading Change: Why Transformation Effort Fails?. Harvard Business Review on Change. Ed.ke-6. Boston: Harvard Business Press (1996): 1-21.

Lewis, W.G., Pun. K.F. and Lalla, T.R.M.. Empirical Investigation of the Hard and Soft Criteria of TQM in ISO 9001 Certified Small and Medium-Sized Enterprises. International Journal of Quality and Reliability Management, 23, no.8, (2006): 964-985.

Low, S.P. and Alfelor, W.M., Cross-cultural Influences on Quality Management Systems. Work Study 49, no.4 (2000), 134-144.

Low, S.P. and Omar, H.F., 1997. The Effective Maintenance of Quality Management Systems in the Construction Industry. International Journal of Quality and Reliability Management 14, no.8 (1997): 768-790.

Madu, C.N., Handbook of TQM. London: Kluwer Academic, 1998. Magd, H. and Curry, A., ISO 9000 and TQM. The TQM Magazine 15, no.4 (2003): 244-256.

Rahman, Afzal Ur. Doktrin Ekonomi Islam. Zaharah Salleh. Terj. Kuala Lumpur: Dewan Bahasa dan Pustaka, 1999.

Seaver, M. Implementing ISO 9000:2000. England: Gower Publishing Company, 2001. 